\title{
Nutritional quality and health benefits of "Okra" (Abelmoschus esculentus): A review
}

\author{
Habtamu Fekadu Gemede ${ }^{1,4,}$, Negussie Ratta ${ }^{2}$, Gulelat Desse Haki ${ }^{3}$, Ashagrie Z. Woldegiorgis ${ }^{4}$, \\ Fekadu Beyene ${ }^{1}$
}

${ }^{1}$ Department of Food Technology and Process Engineering, Wollega University, P.O. Box: 395, Nekemte, Ethiopia

${ }^{2}$ Department of Chemistry, Addis Ababa University, P.O. Box 1176, Addis Ababa, Ethiopia

${ }^{3}$ Department of Food Science and Technology, Botswana Collage of Agriculture, Botswana University, Gaborone, Botswana

${ }^{4}$ Center for Food Science and Nutrition, Addis Ababa University, P.O. Box 1176, Addis Ababa, Ethiopia

\section{Email address:}

fekadu_habtamu@yahoo.com (H. F. Gemede)simbokom@gmail.com (H. F. Gemede)

\section{To cite this article:}

Habtamu Fekadu Gemede, Negussie Ratta, Gulelat Desse Haki, Ashagrie Z. Woldegiorgis, Fekadu Beyene. Nutritional Quality and Health Benefits of "Okra" (Abelmoschus esculentus): A Review. International Journal of Nutrition and Food Sciences.

Vol. 4, No. 2, 2015, pp. 208-215. doi: 10.11648/j.ijnfs.20150402.22

\begin{abstract}
Okra" (Abelmoschus esculentus) is an economically important vegetable crop grown in tropical and sub-tropical parts of the world. This paper was aimed to review nutritional quality and potential health benefits of edible parts of "Okra". "Okra" is a multipurpose crop due to its various uses of the fresh leaves, buds, flowers, pods, stems and seeds. "Okra" immature fruits, which are consumed as vegetables, can be used in salads, soups and stews, fresh or dried, fried or boiled. It offers mucilaginous consistency after cooking. Often the extract obtained from the fruit is added to different recipes like stews and sauces to increase the consistency. "Okra" mucilage has medicinal applications when used as a plasma replacement or blood volume expander. The mucilage of "Okra" binds cholesterol and bile acid carrying toxins dumped into it by the liver. "Okra" seeds are a potential source of oil, with concentrations varying from $20 \%$ to $40 \%$, which consists of linoleic acid up to $47.4 \%$. "Okra" seed oil is also a rich source of linoleic acid, a polyunsaturated fatty acid essential for human nutrition. "Okra" has been called "a perfect villager's vegetable" because of its robust nature, dietary fiber, and distinct seed protein balance of both lysine and tryptophan amino acids. The amino acid composition of "Okra" seed protein is comparable to that of soybean and the protein efficiency ratio is higher than that of soybean and the amino acid pattern of the protein renders it an adequate supplement to legume or cereal based diets. "Okra" seed is known to be rich in high quality protein especially with regards to its content of essential amino acids relative to other plant protein sources. "Okra" is a powerhouse of valuable nutrients, nearly half of which is soluble fibre in the form of gums and pectins which help to lower serum cholesterol, reducing the risk of heart diseases. The other fraction of "Okra" is insoluble fibre, which helps to keep the intestinal tract healthy. "Okra" is also abundant with several carbohydrates, minerals and vitamins, which play a vital role in human diet and health. "Okra" is rich in phenolic compounds with important biological properties like quartering and flavonol derivatives, catechin oligomers and hydroxycinnamic derivatives. "Okra" is also known for being high in antioxidants activity. "Okra" has several potential health beneficial effects on some of the important human diseases like cardiovascular disease, type 2 diabetes, digestive diseases and some cancers. Overall, "Okra” is an important vegetable crop with a diverse array of nutritional quality and potential health benefits.
\end{abstract}

Keywords: Okra, Nutritional, Quality, Health, Edible, Oil

\section{Introduction}

"Okra" (Abelmoschus esculentus) is one of the most widely known and utilized species of the family Malvaceae [1] and an economically important vegetable crop grown in tropical and sub-tropical parts of the world $[2,3,4]$. This crop is one of the most widely known and utilized species of the family Malvaceae [1]. "Okra" plant was previously included in the genus Hibiscus. Later, it was designated to Abelmoschus, which is distinguished from the genus Hibiscus [5].

"Okra" originated in Ethiopia [6] and was then propagated in North Africa, in the Mediterranean, in Arabia and India by the 12th century BC [7]. Considering the little contact 
between Ethiopia and the rest of the world within historic times, it is not surprising that little is known about the early history and distribution of "Okra". The routes by which "Okra" was taken from Ethiopia to North Africa, the eastern Mediterranean, Arabia, and India, and when, are by no means certain [8].

"Okra" is known by many local names in different parts of the world. It is called lady's finger in England, gumbo in the United States of America, guino-gombo in Spanish, guibeiro in Portuguese and bhindiin India [9,10]. In its origin of Ethiopia it is also called Kenkase (Berta), Andeha (Gumuz), Bamia (Oromica/Amharic). The name "Okra" derives from one of Niger-Congo group of languages (the name for "Okra" in the Twi language is nkuruma) [11]. The term "Okra" was in the use of English by the late 18th century [12].

"Okra" is suitable for cultivation as a garden crop as well as on large commercial farms [13]. "Okra" plants are grown commercially in many countries such as India, Japan, Turkey, Iran, Western Africa, Yugoslavia, Bangladesh, Afghanistan, Pakistan, Myanmar, Malaysia, Thailand, India, Brazil, Ethiopia, Cyprus and in the Southern United States [14].

"Okra" is a multipurpose crop due to its various uses of the fresh leaves, buds, flowers, pods, stems and seeds [15]. "Okra" immature fruits (green seed pods), which are consumed as vegetables, can be used in salads, soups and stews, fresh or dried, fried or boiled [9]. It offers mucilaginous consistency after cooking. Often the extract obtained from the fruit is added to different recipes like soups, stews and sauces to increase the consistency. "Okra" mucilage has medicinal applications when used as a plasma replacement or blood volume expander. The mucilage of "Okra" binds cholesterol and bile acid carrying toxins dumped into it by the liver. The immature pods are also used in making pickle. The entire plant is edible and is used to have several foods $[16,17]$.

"Okra" seeds are source of oil and protein. "Okra" seeds have been used on a small scale for oil production. It can be also used as non-caffeinated substitute for coffee. "Okra" seeds may be roasted and ground to form a caffeine-free substitute for coffee [18]. "Okra" also has industrial applications and is used in confectionary [19]. To promote the use of indigenous vegetables like "Okra" that have play significant role in mitigate food insecurity and alleviate malnutrition in the country. However, "Okra" has been considered a minor crop and no attention was paid to its improvement in the international research program in past [20].

On the other hand, the demand for vegetable oils is rapidly increasing due to the growing human population and the expanding oil industry with health promoting oil components, the exploration of some underutilized and newer resources of vegetable oils is of much concern [21]. "Okra", which is currently grown mainly as a vegetable crop, has potential for cultivation as an essential oilseed crop because "Okra" seeds contain high amount of oil $(20-40 \%)[10,22]$. However, there is also no comprehensive literature information regarding characteristics of the oils produced from "Okra" seeds. Therefore, this review was aimed to assess literature regarding the nutritional quality and potential health benefits of edible parts of "Okra" (Abelmoschus esculentus) vegetable. The oil compositions of "Okra" seed was also discussed in order to provide further reliable information about health promoting oil components of "Okra" seeds.

\section{Nutritional Composition of "Okra"}

"Okra" is more a diet food than staple [23]. "Okra" seeds have been used on a small scale for oil production. Lipid components greatly contribute to the nutritional and sensory value of almost all types of foods. Nature provides a large number of fats that differ in their chemical and functional properties. Four classes of lipids are habitually found in vegetable oils: triacylglycerols, diacylglycerols, polar lipids, and free fatty acids. The fatty acid composition determines the physical properties, stability, and nutritional value of lipids. The most naturally occurring storage lipids are triacylglycerols. Triacylglycerols are natural compounds that consist of saturated and unsaturated fatty acids that differ in the length of their acyl chains and the number and positions of double bonds: saturated, monoenoic, and polyunsaturated fatty acids that differ with respect to detailed fatty acid composition. Monoenoic fatty acids and polyunsaturated fatty acids are structurally distinguished by the presence of repeating methylene units. These units produce an extremely flexible chain that rapidly reorients through conformational states and constitutes an influential group of molecules that promote health [24]. "Okra" seeds from Greece are a potential source of oil, with concentrations varying from $20 \%$ to $40 \%[10,22]$, depending on the extraction method. The oil mainly consists of linoleic acid (up to 47.4\%) [3]. "Okra" seed oil is a rich source of linoleic acid, a polyunsaturated fatty acid essential for human nutrition [25].

Proteins play a particularly important role in human nutrition. The amino acid contents, proportions, and their digestibility by humans characterize a protein's biological value [26]. "Okra" has been called "a perfect villager's vegetable" because of its robust nature, dietary fiber, and distinct seed protein balance of both lysine and tryptophan amino acids (unlike the proteins of cereals and pulses) [20,27]. The amino acid composition of "Okra" seed protein is comparable to that of soybean and the protein efficient ratio is higher than that of soybean [28], and the amino acid pattern of the protein renders it an adequate supplement to legume or cereal based diets [29]. "Okra" seed is known to be rich in high quality protein especially with regards to its content of essential amino acids relative to other plant protein sources $[2,23]$. Hence, it plays a vital role in the human diet [30].

"Okra" also contains carbohydrates and vitamins $[12,31,32]$, and plays a vital role in human diet $[4,33]$. Consumption of young immature "Okra" pods is important as fresh fruits, and it can be consumed in different forms [9]. Fruits can be boiled, fried or cooked [34]. The composition of "Okra" pods per $100 \mathrm{~g}$ edible portion $(81 \%$ of the product as purchased, ends trimmed) is: water $88.6 \mathrm{~g}$, energy 144.00 $\mathrm{kJ}$ (36 kcal), protein $2.10 \mathrm{~g}$, carbohydrate $8.20 \mathrm{~g}$, fat $0.20 \mathrm{~g}$, 
fibre $1.70 \mathrm{~g}$, Ca $84.00 \mathrm{mg}, \mathrm{P} 90.00 \mathrm{mg}$, Fe $1.20 \mathrm{mg}, \beta$ carotene $185.00 \mu \mathrm{g}$, riboflavin $0.08 \mathrm{mg}$, thiamin $0.04 \mathrm{mg}$, niacin $0.60 \mathrm{mg}$, ascorbic acid $47.00 \mathrm{mg}$.

The composition of "Okra" leaves per $100 \mathrm{~g}$ edible portion is: water $81.50 \mathrm{~g}$, energy $235.00 \mathrm{~kJ}(56.00 \mathrm{kcal})$, protein 4.40 $\mathrm{g}$, fat $0.60 \mathrm{~g}$, carbohydrate $11.30 \mathrm{~g}$, fibre $2.10 \mathrm{~g}$, Ca 532.00 $\mathrm{mg}, \mathrm{P} 70.00 \mathrm{mg}$, Fe $0.70 \mathrm{mg}$, ascorbic acid $59.00 \mathrm{mg}, \beta-$ carotene $385.00 \mu \mathrm{g}$, thiamin $0.25 \mathrm{mg}$, riboflavin $2.80 \mathrm{mg}$, niacin $0.20 \mathrm{mg}$ [32,35]. Carbohydrates are mainly present in the form of mucilage [36,37]. That of young fruits consists of long chain molecules with a molecular weight of about 170,000 made up of sugar units and amino acids. The main components are galactose (25\%), rhamnose (22\%), galacturonic acid (27\%) and amino acids (11\%). The mucilage is highly soluble in water. Its solution in water has an intrinsic viscosity value of about $30 \%$.

Potassium, Sodium, Magnesium and Calcium are the principal elements in pods, which contain about $17 \%$ seeds. Presence of Iron, Zink, Manganese and Nickel also has been reported [38]. Fresh pods are low in calories (20 per $100 \mathrm{~g})$, practically no fat, high in fiber, and have several valuable nutrients, including about $30 \%$ of the recommended levels of vitamin $\mathrm{C}$ (16 to $29 \mathrm{mg}$ ), 10 to $20 \%$ of folate ( 46 to $88 \mathrm{mg}$ ) and about $5 \%$ of vitamin A (14 to 20 RAE). Both pod skin (mesocarp) and seeds are excellent source of zinc ( $80 \mathrm{mg} / \mathrm{g}$ ) [39]

"Okra" seed is mainly composed of oligomeric catechins $(2.5 \mathrm{mg} / \mathrm{g}$ of seeds) and flavonol derivatives $(3.4 \mathrm{mg} / \mathrm{g}$ of seeds), while the mesocarp is mainly composed of hydroxycinnamic and quercetin derivatives $(0.2$ and $0.3 \mathrm{mg} / \mathrm{g}$ of skins). Pods and seeds are rich in phenolic compounds with important biological properties like quartering derivatives, catechin oligomers and hydroxycinnamic derivatives [12]. These properties, along with the high content of carbohydrates, proteins, glycol-protein, and other dietary elements enhance the importance of this foodstuff in the human diet $[12,40]$.

Dried "Okra" sauce (pods mixed with other ingredients and regularly consumed in West Africa) does not provide any beta carotene (vitamin A) or retinol [41]. However, fresh "Okra" pods are the most important vegetable source of viscous fiber, an important dietary component to lower cholesterol [42]. Seven-days-old fresh "Okra" pods have the highest concentration of nutrients [43].

Seed as potential edible oil and flour source

"Okra" seeds contain about 20 to $40 \%$ oil $[10,22]$. The bark fibre is easy to extract. It is white to yellow in colour, strong but rather coarse. Tests conducted in China suggest that an alcohol extract of "Okra" leaves can eliminate oxygen free radicals, alleviate renal tubular-interstitial diseases, reduce proteinuria, and improve renal function [36,37]. "Okra" seed can be dried, and the dried seeds are a nutritious material that can be used to prepare vegetable curds, or roasted and ground to be used as coffee additive or substitute [44].

"Okra" seed oil yield is comparable to most oil seed crops except oil palm and soybean [20]. Moreover, "Okra" seed oil has potential hypocholesterolemic effect. The potential for wide cultivation of "Okra" for edible oil as well as for cake is very high [20]. "Okra" seed flour could also be used to fortify cereal flour [45]. For example, supplementing maize ogi with "Okra" meal increases protein, ash, oil and fiber content [46]. "Okra" seed flour has been used to supplement corn flour for a very long time in countries like Egypt to make better quality dough. However, long-term rodent/animal feeding trials would be pertinent before making final recommendations for wider consumption of "Okra" seed flour [20].

The enormous nutritional and other biological activities in the pods and seeds were reported by Agbo et al., [43]; Arapitsas, [12], and Kumar et al., [47]. The "Okra" pods were reported to have viscous fiber and lower cholesterol content [42,47]. "Okra" seeds were determined to have appreciable protein content according to Akingbala et al., [46]. The variations in polysaccharides found in the mucilage are higher in "Okra" pods according to Hirose et al., [48], and Sengkhamparn et al., [49].

Green vegetables contain valuable chlorophyll [50]. Chlorophyllin as an important component of chlorophyll was reported for enormous health benefits. The physiological and biochemical activities of phenolic compounds as antioxidant, anti-inflammatory and anti-microbial were also reported by Ali and Deokule, [51]; Manach et al., [40], and Middleton, [52]. Marinova et al., [53] proved the higher values of phenolic and flavonoid values, ratios and distributions in some Bulgarian vegetables and fruits. Generally, fruits and vegetables have shown the basic useful properties especially in providing an excellent health and nutritional qualities in the area of prevention and delay in the onset of chronic diseases and the provision of vitamins and enzymes necessary for proper body function [54].

\section{Mucilage and Its Potential}

"Okra" mucilage refers to the thick and slimy substance found in fresh as well as dried pods. Mucilaginous substances are usually concentrated in the pod walls and are chemically acidic polysaccharides associated with proteins and minerals [55]. Although nature of the polysaccharides varies greatly, neutral sugars rhamnose, galactose and galacturonic acid have been reported often $[48,49]$. The "Okra" mucilage can be extracted as a viscous gum using various procedures. Such diversity in the extraction procedures seems to contribute to the observed variability in the mucilage chemical composition [56]. "Okra" mucilage is a renewable and inexpensive source of biodegradable material. Its physical and chemical properties include high water solubility, plasticity, elasticity and viscosity [57].

Most physical and chemical properties are influenced by factors such as temperature, $\mathrm{pH}$, sugar and salt contents, and storage time $[55,58]$. "Okra" mucilage has potential for use as food, non-food products, and medicine. Food applications include use as a whipping agent for reconstituted egg whites, as an additive in the formulation of flour-based adhesives, and as an additive in India for clarifying sugarcane juice. Non-food applications include brightening agents in electro deposition of 
metals, as a deflocculant in paper and fabric production, and as a protectant to reduce friction in pipe-flow [56,57]. Polysaccharides can be combined with acrylamide to develop new biodegradable polymeric materials [59]. Potential of mucilage for medicinal applications includes uses as an extender of serum albumin [57], as tablet binder [60] and as suspending agent in formulations [37]. "Okra" mucilage is used in Asian medicine as a protective food additive against irritating and inflammatory gastric diseases [61].

\section{Health Benefits of "Okra"}

In recent years, increasing attention has been paid to the role of diet in human health [62]. The high intake of plant products is associated with a reduced risk of a number of chronic diseases, such as atherosclerosis and cancer [63]. These beneficial effects have been partly attributed to the compounds which possess antioxidant activity. The major antioxidants of vegetables are vitamins $\mathrm{C}$ and $\mathrm{E}$, carotenoids, and phenolic compounds, especially flavonoids. These antioxidants scavenge radicals and inhibit the chain initiation or break the chain propagation (the second defense line). Vitamin E and carotenoids also contribute to the first defense line against oxidative stress, because they quench singlet oxygen [64]. Flavonoids as well as vitamin $\mathrm{C}$ showed a protective activity to $\alpha$-atocopherol in human LDL, and they can also regenerate vitamin $\mathrm{E}$, from the $\alpha$-chromanoxy radical [65].

Nutrient antioxidants may act together to reduce reactive oxygen species level more effectively than single dietary antioxidants, because they can function as synergists [66]. In addition, a mixture containing both water-soluble and lipidsoluble antioxidants is capable of quenching free radicals in both aqueous and lipid phases [67]. For example, with the liposome oxidation method, the activity of combination of quercetin or catechins plus $\alpha$-tocopherol was significantly higher than the sum of the individual activities. Combinations of $\alpha$-tocopherol or vitamin $\mathrm{C}$ plus phenolic compounds also provided synergistic effects in human erythrocyte membrane ghosts and phosphatidylcholine liposome systems [68].

"Okra" seed is rich in protein and unsaturated fatty acids such as linoleic acid [2]. In some countries, "Okra" also is used in folk medicine as antiulcerogenic, gastroprotective, diuretic agents [69]. However, little information on antioxidant capabilities of major phenolic compounds from "Okra" seed is available. "Okra" is also a popular health food due to its high fiber, vitamin $\mathrm{C}$, and folate content. "Okra" is also a good source of calcium and potassium. "Okra" pod contain thick slimy polysaccharides, which are used to thicken soups and stews, as an egg white substitute, and as a fat substitute in chocolate bar cookies and in chocolate frozen dairy dessert [49].

"Okra" is also known for being high in antioxidants activity with different parts of the plant [70]. Atawodi et al., [71] has reported in vitro antioxidant assay of methanol extract of "Okra" fruits. They have done antioxidant/radical scavenging activities by xanthine oxidase and 2deoxyguanosine methods and reported 50\% inhibitory concentration values of 25 and $43 \mathrm{ml}$. In addition, Arapitsas, [12], reported that "Okra" seed is rich in Phenolic compounds, mainly composed of flavonol derivatives and oligomeric catechins. According to Khomsug et al., [72], total phenolic content of pulped and seeds of "Okra" extracts as $10.75 \pm 0.02 \mathrm{mg}$ GAE $/ 100 \mathrm{~g}$ extract and $142.48 \pm 0.02 \mathrm{mg}$ GAE/100g extract which corresponds with scavenging activities. Besides they have also found procycanidin B2 as predominant phenolic compound followed by procycanidin $\mathrm{B} 1$ and rutin in seeds. In pulped seed catechin, procycanidin $\mathrm{B} 2$, epicatechin and rutin are reported to be present. It is quite important to the see that roasting $\left(1600^{\circ} \mathrm{C}\right.$ for $10-60$ minutes) increased the nutrient composition and antioxidant activity of the seeds whereas pre-treatment (soaking and blanching) increased the nutrient composition, but decreases antioxidant activity [73]. Ansari, [74], reported "Okra" extract as in vitronon-enzymatic inhibitior of lipid peroxidation in liposomes. A. esculentus peel and seed powder contains significant in vivo antioxidant property in streptozotocin-induced diabetic rats.

Administration of different doses of peel and seed powder significantly increased liver, kidney and pancreas superoxide dismutase, catalase, glutathione peroxidase, reduced glutathione levels and decreased thiobarbituric acid reactive substances (TBARS) $(\mathrm{P}<0.001)$ levels in diabetic rats compared to diabetic control rats. Liao et al., [75] has done a comparative analysis of total phenolics and total flavonoids and antioxidant ability of different organs (flower, fruit, leaf, and seed) and different enrichment fractions of water extracts of the A. esculentusplant. They confirmed fruitful presence of total phenolics and total flavonoids related to antioxidant ability in all the extracts of the plant organs although percentage varied. In flower of "Okra" highest amount of total phenolics and totalflavonoids were found [75]. This data suggests "Okra" as a good contributor to the antioxidant status and promising chemopreventive agent as described in several traditional medicines for human race. "Okra" is abundant with several vitamins, minerals, and nutrients that handles the health advantages the plant provides. Here are a few of "Okra"'s health advantages:

"Okra" contain high fiber, which "helps to stabilize blood sugar by regulating the rate at which sugar is absorbed from the intestinal tract". Because of fiber along with other nutrition, "Okra" shows useful for minimizing blood sugar levels within the body, assisting along with diabetes. The fiber likewise helps support blood sugar levels level simply by slowing down sugar assimilation through the intestines [76]. The frequent usage of "Okra" might help avoid kidney disease. Within the research, "those who consumed "Okra" every day decreased clinical indications of kidney damage a lot more than the ones that simply consumed a diabetic diet." This ties along with diabetes, as almost $50 \%$ of kidney disease cases are generated by diabetes [61].

"Okra" is used to treat digestive issues. The polysaccharides present in immature "Okra" pods possessed 
considerable antiadhesive properties (i.e. they help remove the adhesive between bacteria and stomach tissue, preventing the cultures from spreading). "Okra"'s polysaccharides were particularly effective at inhibiting the adhesion of Helicobacter pylori, a bacterium that dwells in the stomach and can cause gastritis and gastric ulcers if left unchecked. Therefore, eating more "Okra" can keep our stomach clean and create an environment that prevents destructive cultures from flourishing [77]. "Okra" is used to supports colon health. It smoothly sails down our colon, absorbing all toxins and excess water in its path. "Okra" is filled with dietary fiber, that is required for colon health and digestive health all together. The fiber "Okra" offers helps to cleanse the intestinal system, letting the colon to operate at higher amounts of effectiveness. In addition, the vitamin A plays a role in wholesome mucous membranes, assisting the digestive system to function adequately [78].

"Okra" is used to promote healthy skin and blood. One hundred grams of "Okra" also contain approximately 27 percent of our RDI of vitamin $\mathrm{C}$ and 50 percent of our RDI of vitamin K. Vitamin C is, of course, an essential antioxidant that aids in the growth and repair of bodily tissues. For this reason, eating more "Okra" can rejuvenate our skin and hair, and also shield us from degenerative diseases associated with long-term free radical damage. Vitamin K, on the other hand, plays an important role in blood clot formation. If you suffer from regular nosebleeds, bleeding gums, heavy menstrual bleeding, or easy bruising, your blood might be too thin. Consider adding more vitamin K-rich foods like "Okra" to your diet to improve your blood's ability to coagulate [79].

"Okra" is used to promotes a healthy of the pregnancy. An incredibly essential B vitamin for creating and maintaining new cells, foliate is a vital substance for optimum pregnancy. The vitamin aids in preventing birth defects just like spina bifida and enables the baby to develop completely. Vitamin C is additionally required for baby development. "Okra" is full of both foliate and vitamin C. The high quantity of foliate included in the "Okra" is helpful for the fetus while pregnant. Foliate is a vital nutrient that increases the growth and development of the fetus' brain. The high quantity of folic acid within "Okra" performs a huge role within the neural tube formation of the fetus through the fourth to the 12th week of pregnancy [80].

"Okra" is used to improves heart health. The soluble fiber within "Okra" helps you to reduce serum cholesterol and therefore decreases the chance of cardiovascular disease. Consuming "Okra" is an efficient method to manage the body's cholesterol level. "Okra" is additionally loaded with pectin that can help in reducing high blood cholesterol simply by modifying the creation of bile within the intestines [76]. "Okra" is also used to improves good eyesight. The "Okra" pods are fantastic options for Vitamin A and also beta carotene that are both important nourishment for sustaining an excellent eye-sight along with healthy skin [81]. Additionally, these types of important nourishment also assist inhibits eye associated illnesses along with problems on the skin. "Okra" is better ingested when joined along with other healthy veggies. Consuming "Okra" has truly numerous advantages, simply bear in mind to eat natural veggies as opposed to processed veggies [77].

"Okra" is used to controls the body's cholesterol level. There are numerous significant illnesses related to high cholesterol level of the entire body. Managing the body's cholesterol level is nearly difficult because it's hard to avoid foods loaded with cholesterol content. One of the better health advantages of consuming "Okra" is definitely the powerful management of the human body's high cholesterol level [82]. This healthy vegetable is beneficial in slimming down and also decreasing cholesterol therefore keeps a healthy and also low cholesterol body. "Okra" have been taken advantage by diet advisors due to these qualities [80].

Generally, "Okra" is used to stabilize blood sugar by regulating the rate at which sugar is absorbed from the intestinal tract. It is a good vegetable for those feeling weak, exhausted, and suffering from depression and it is also used in ulcers, lung inflammation, sore throat as well as irritable bowel. "Okra" is good for asthma patients and it also normalizes blood sugar and cholesterol levels [82]. Previous studies reported that "Okra" polysaccharide possesses anticomplementary and hypoglycemic activity in normal mice [83]. Also, "Okra" polysaccharide lowers cholesterol level in blood and may prevent cancer by its ability to bind bile acids [81,84]. Additionally, "Okra" seed possess blood glucose normalization and lipid profiles lowering action in diabetic condition [85].

\section{Conclusion}

The information presented here shows the potential nutritional importance of "Okra" and its role in improved nutrition and health. It is an affordable source of protein, carbohydrates, minerals and vitamins, dietary fibre and health promoting fatty acids. Scientific studies provide some evidence to support the potential beneficial effects of "Okra" components in lowering the risk for various chronic diseases, although information pertaining to the role of edible plant parts of "Okra" in disease prevention and the mechanisms of action are limited to date. This is due to the complex nature of disease etiology and various factors impacting their occurrence. It is imperative the scientific community continues to unravel the mechanisms involved in disease prevention and determine how food bio-actives from such foods as "Okra" can influence human health. Further research, needs to be performed to provide compelling evidence for the direct health benefits of "Okra" consumption. Therefore, promoting the consumption of traditional vegetables such as "Okra" could provide cheap sources of macro and micronutrients and mineral elements that can improve the nutritional status of resource-poor subsistence farmers in the area in particular and in Ethiopia in general. Furthermore, this vegetable can also be used as an indispensable tool when it comes to reducing the prevalence of malnutrition, especially among resource-constrained urban households in addition to rural household. Consumption of 
"Okra" by both low-income and high-income groups can also used as a means of dietary diversification approach.

\section{References}

[1] Naveed, A., Khan, A.A., \& Khan, I.A. (2009). Generation mean analysis of water stress tolerance in "Okra" (Abelmoschus esculentus L.). Pak. J. Bot., 41: 195-205.

[2] Oyelade, O.J., Ade-Omowaye, B.I.O., and Adeomi, V.F. (2003). Influence of variety on protein, fat contents and some physical characteristics of "Okra" seeds. J. Food Eng., 57: $111-114$.

[3] Andras, C.D., Simandi, B., Orsi, F., Lambrou, C., Tatla, D.M., Panayiotou, C., Domokos, J., \& Doleschall. F. (2005). Supercritical carbon dioxide extraction of "Okra" (Hibiscus esculentus L.) seeds. J. Sci. Food Agric., 85: 1415-1419.

[4] Saifullah, M., \& Rabbani, MG. (2009). Evaluation and characterization of "Okra" (Abelmoschus esculentus L. Moench.) genotypes. SAARC J. Agric. 7: 92-99.

[5] Aladele, S.E., Ariyo, O.J. \& Lapena, R.de. (2008). Genetic relationships among West African "Okra" (Abelmoschuscaillei)and Asian genotypes (Abelmoschus esculentus) using RAPD. Indian Journal of Biotechnology.7 (10):1426-1431.

[6] Sathish, D., and Eswar, A. (2013). A Review on: Abelmoschus esculentus ("Okra”). Int. Res J Pharm. App Sci., 2013; 3(4):129-132.

[7] Nzikou, J., Mvoula-Tsieri, M., \& Matouba, E. (2006). A study on gumbo seed grown in Congo Brazzaville for its food and industrial applications. African Journal of Biotechnology Vol. 5 (24), pp. 2469-2475.

[8] Tindall, HD. (1983): Vegetables in the tropics. Macmillan Education Limited, London, UK.

[9] Ndunguru, J., \& Rajabu, AC. (2004). Effect of "Okra" mosaic virus disease on the above-ground morphological yield components of "Okra" in Tanzania. Scienta Horticulturae, 99: 225-235.

[10] Sorapong Benchasr, (2012). "Okra" (Abelmoschus esculentus(L.) Moench) as a Valuable Vegetable of the World. Ratar. Povrt. 49:105-112.

[11] Benjawan, C., Chutichudet, P., \& Kaewsit, S. (2007). Effect of green manures on growth yield and quality of green "Okra" (Abelmoschus esculentusL) har lium cultivar. Pakistan J. Biological Sci. 10: 1028-1035.

[12] Arapitsas, P. (2008). Identification and quantification of polyphenolic compounds from "Okra" seeds and skins. Food Chem. 110:1041-1045.

[13] Rubatzky, VE., \& Yamaguchi, M. (1997): World vegetables: principles, production, and nutritive values. Chapman and Hall, New York, USA.

[14] Qhureshi, Z. (2007). Breeding investigation in bhendi (Abelmoschus esculentus (L.) Moench). Master Thesis, University of Agriculture Sciences, GKVK, Bangalore.

[15] Mihretu, Y., Wayessa, G., \& Adugna, D. (2014). Multivariate Analysis among "Okra" (Abelmoschus esculentus (L.)
Moench) Collection in South Western Ethiopia. Journal of Plant Sciences 9(2):43-50.

[16] Madison, D. (2008). Renewing America's Food Traditions. Chelsea Green Publishing. p. 167.

[17] Maramag, R. P. (2013). Diuretic potential of Capsicum frutescens L., Corchorus oliturius L., and Abelmoschus esculentus L. Asian journal of natural and applied science, 2 (1). 60-69.

[18] Calisir, S., \& Yildiz, M. U. (2005). A study on some physicochemical properties of Turkey"Okra" (Hibiscus esculenta) seeds. Journal of Food Engineering, 68, 73-78.

[19] Adetuyi, F.O., Osagie, A.U., \& Adekunle, A.T. (2011). Nutrient, antinutrient, mineral and zinc bioavailability of "Okra" Abelmoschus esculentus (L) Moench Variety. Am. J. Food. Nutr, 2011, 1(2): 49-54.

[20] Sanjeet K., Sokona D., Adamou H., Alain R., Dov P., \& Christophe, K. (2010). "Okra" (Abelmoschus spp.) in West and Central Africa: Potential and progress on its improvement. African Journal of Agricultural Research Vol. 5(25), pp. 35903598 .

[21] Schalau, J. (2002). Backyard Gardener. Available at http://ag.arizona.edu. /yavapai/anr/hort/byg/.

[22] MEF, (2013). Biology of "Okra". Series of crop specific biology document. Ministry of Environmental and Forest Government of India. p1-8.

[23] National Research Council, (2006). "“'Okra”". Lost Crops of Africa: Volume II: Vegetables. Lost Crops of Africa. 2. National Academies Press. ISBN: 0-309-66582-5, 378 pages.

[24] Vermerris, W., \& Nicholson, R., (2006). Phenolic Compound Biochemistry, Springer, Dordrecht, The Netherlands.

[25] Savello, P.A., Martins, F., and Hull, W. (1980). Nutrition composition of "Okra" seed meals. J. Agric. Food Chem.,28: 1163-1166.

[26] Ewa, C, Agnieszka, G, \& Adametal, F. (2011).“The content of protein and of amino acids in Jerusalem artichoke tubers (Helianthus tuberosus L.) of red variety Rote Zonenkugel,"Acta Scientiarum Polonorum, Technologia Alimentaria, vol.10, no.4, pp.433-441.

[27] Holser, R., \& Bost, G. (2004). "Hybrid Hibiscus seed oil compositions," Journal of the American Oil Chemists' Society, vol.81,no. 8, pp. 795-797, 2004.

[28] Adetuyi, F., Ajala, L., \& Ibrahim, T. (2012). Effect of the addition of defatted "Okra" seed (abelmoschus esculentus) flour on the chemical composition, functional properties and zn bioavailability of plantain (musa paradisiacal linn) flour. JMBFS / Adetuyi et al. 2012: 2 (1) 69-82.

[29] Ndangui, C.B., Kimbonguila, A., Nzikou, J.M., Matos, L., Pambou, N.P .G., Abena, A.A., Silou, Th., Scher, J., \& De sobry, S. (2010). Nutritive Composition and Properties Physico-chemical of gumbo (Abelmoschus esculentu s L.) Seed and Oil. Research Journal of Environmentaland Earth Sciences 2(1): 49-54.

[30] Farinde, A., Owolarafe, O., \& Ogungbemi, I. (2007). “An overview of production, processing, marketing and utilisation of "Okra" in egbedore local government area of Osun State, Nigeria,"Agricultural Engineering, vol.4, pp.1-17. 
[31] Owolarafe, OK., \& Shotonde, HO. (2004). Some physical properties of fresh "Okra" fruit. J. Food Engin. 63: 299-302.

[32] Gopalan, C., Sastri, SBV., \& Balasubramanian, S. (2007). Nutritive value of Indian foods, National Institute of Nutrition (NIN), ICMR, India.

[33] Kahlon, TS., Chapman, MH., \& Smith, GE. (2007). In vitro binding of bile acids by "Okra" beets asparagus eggplant turnips green beans carrots and cauliflower. Food Chem. 103: 676-680.

[34] Akintoye, HA., Adebayo, AG., \& Aina, OO. (2011). Growth and yield response of "Okra" intercropped with live mulches. Asian J. Agric. Res. 5: 146-153.

[35] Varmudy, V. (2011). Marking survey need to boost "Okra" exports. Department of economics, Vivekananda College, Puttur, Karnataka, India.

[36] Liu, IM., Liou, SS., Lan, TW., Hsu, FL., \& Cheng, JT. (2005). Myricetin as the active principle of Abelmoschus moschatusto lower plasma glucosein streptozotocin-induced diabetic rats. Planta Medica 71: 617-621.

[37] Kumar, R., Patil, MB., Patil, SR., \& Paschapur, MS. (2009). Evaluation of Abelmoschus esculentus mucilage as paracetamol suspension. Intl. J. Pharm. Tech. Res. 1:658-665.

[38] Moyin-Jesu, EI. (2007). Use of plant residues for improving soil fertility pod nutrients root growth and pod weight of "Okra" Abelmoschus esculentum L. Bioresour. Tech. 98: 2057-2064.

[39] Cook, JA., Jagt, DJ., Pastuszyn, A., Mounkaila, G., Glew, RS., Millson, M., and Glew, RH. (2000). Nutrient and chemical composition of 13 wild plant foods of Niger. J. Food Comp. Anal., 13: 83-92.

[40] Manach, C., Williamson, G., Morand, C., Scalbert, A., \& Remesy, C. (2005). Bioavailability and bioefficacy of polyphenols in humans. Amer. J. Clinical Nutrit., 81: 230-242.

[41] Avallone, S., Tiemtore, TWE., Rivier, CM., \& Treche, S. (2008). Nutritional value of six multi-ingredient sauces from Burkina Faso. J. Food Comp. Anal. 21:553-558.

[42] Kendall, CWC., \& Jenkins, DJA. (2004). A dietary portfolio: maximal reduction of low-density lipoprotein cholesterol with diet. Current Atherosclerosis Reports 6:492-498.

[43] Agbo, AE., Gnakri, D., Beugre, GM., Fondio, L., \& Kouame, C. (2008). Maturity degree of four "Okra" fruit varieties and their nutrients composition. Elect. J. Food Plant Chem. 5:1-4.

[44] Moekchantuk, T., Kumar, P. (2004). Export “Okra” production in Thailand. Inter-country programme for vegetable IPM in South \& SE Asia phase II Food \& Agriculture Organization of the United Nations, Bangkok, Thailand

[45] Adelakun, OE., Oyelade, OJ., Ade-Omowaye, BIO., Adeyemi, IA., \& Vande, M. (2008). Influence of pre-treatment on yield, chemical and antioxidant properties of Nigerian "Okra" seed (Abelmoschus esculentus Moench) flour: DOI: 10.1016/j.fct.2008.12.023.

[46] Akingbala, JO., Akinwande, BA., \& Uzo-Peters, PI. (2003). Effects of color and flavor changes on acceptability of ogi supplemented with "Okra" seed meals. Plant Foods Human Nutr, 58:1-9.

[47] Kumar, S., Dagnoko, S., Haougui, S., Ratnadass, A, Pasternak,
D., \& Kouame, C. (2010). "Okra" (Abelmoschus spp.) in West and Central Africa: potential and progress on its improvement. Afr J Agric Res, 5:3590-3598.

[48] Hirose, K., Endo, K., \& Hasegawa, K. (2004). A convenient synthesis of lepidimoide from "Okra" mucilage and its growth promoting activity in hypocotyls. Carbohydr. Poly. 339:9-19.

[49] Sengkhamparn, N., Verhoef, R., Schols, HA., Sajjaanantakul, T., \& Voragen, AGJ. (2009). Characterization of cell wall polysaccharides from "Okra" (Abelmoschus esculentus (L.) Moench). Carbohydr. Res., 344:1824-1832.

[50] Ebermann, R., Alth, G., Kreitner, M., \& Kubin, A. (2006). Natural products derived from plants as potential drugs for the photodynamic destruction of tumor cells. J Photochem Photobiol B. 36(2):95-97.

[51] Ali, A., \& Deokule, SS. (2008). Comparison of phenolic compounds of some edible plant of Iran and India. Pak J Nutr, 7(4):582-585.

[52] Middleton, E. (2000). The effects of plant flavonoids on mammalian cells: Implications for inflammation, heart disease and cancer. Pharm Rev, 52:673-751.

[53] Marinova, D., Ribarova, F., \& Atanassova, M. (2005). Total phenolics and total flavonoids in Bulgarian fruits and vegetables. J Univ Chem Technol Metallur, 40(3):255-260.

[54] Aman, R., Schieber, A., \& Carle, R. (2005). Effects of heating and illumination on trans-cis isomerization and degradation of $\beta$-carotene and lutein in isolated spinach chloroplasts. J Agric Food Chem, 53:9512-9518.

[55] Woolfe, ML., Martin, FC., \& Otchere, G. (1977). Studies on the mucilages extracted from "Okra" fruits (Hibiscus esculentus L.) and baobab leaves (Adansonia digitata L.). J. Sci. Food Agric. 28:519-529.

[56] Ndjouenkeu, R., Goycoolea, FM., Morris, ER., \& Akingbala, JO. (1996). Rheology of "Okra" (Hibiscus esculentus L.) and dika nut (Irvinia gabonensis) polysaccharides. Carbohydrate Polymers 29: 263-269.

[57] BeMiller, JN., Whistler, RL., Barkalow, DG., \& Chen, CC. (1993). Aloea, chia, flax seed, "Okra", psyllium seed, quince seed, and tamarin gums. In: Industrial Gums, Whistler RL, BeMiller JN (eds.), Academic Press, New York, pp. 227-256.

[58] Bhat, UR, \& Tharanathan, RN. (1987). Functional properties of "Okra" (Hibiscus esculentus) mucilage. Starch 39:165-167.

[59] Mishra, A., Clark, JH., \& Pal, S. (2008). Modification of "Okra" mucilage with acrylamide: synthesis, characterization, and swelling behavior. Carbohydr. Poly. 72: 608-615.

[60] Ofoefule, SI., Chukwu, AN., Anayakoha, A., \& Ebebe, IM. (2001). Application of Abelmoschus esculentus in solid dosage forms 1: use as binder for poorly water soluble drug. Indian J. Pharm. Sci. 63: 234-238.

[61] Lengsfeld, C., Titgemeyer, F., Faller, G., \& Hensel, A. (2004). Glycosylated compounds from "Okra" inhibit adhesion of Helicobacter pylori to human gastric mucosa. J. Agric. Food Chem., 52: 1495-1503.

[62] Ohr, L. M. (2004). Dietary antioxidants.Food Technology, 58(10), 67-74.

[63] Gosslau, A., \& Chen, K.Y. (2004). Nutraceuticals, apoptosis, and disease prevention.Nutrition, 20, 95-102. 
[64] Krinsky, N. I. (2001). Carotenoids as antioxidants.Nutrition,17, 815-817.

[65] Davey, M. W., van Montagu, M., Inze, D., Sanmartin, M., Kanellis, A., \& Smirnof, F. (2000). Plant L-ascorbic acid: Chemistry, function, metabolism, bioavailability and effects of processing. Journal of the Science of Food and Agriculture, 80, 825-860.

[66] Rossetto, M., Vanzani, P., Mattivi, F., Lunelli, M., Scarpa, M., \& Rigo, A. (2002). Synergistic antioxidant effect of catechin and malvidin 3-glucoside on free radical-initiated peroxidation of linoleic acid in micelles. Archives of Biochemistry and Biophysics, 408, 239-245.

[67] Trombino, S., Serini, S., Di Nicuolo, F., Celleno, L., Ando, S., \& Picci, N. (2004). Antioxidant effect of ferulic acid in isolated membranes and intact cells. Journal of Agriculture and Food Chemistry, 52, 2411-2420.

[68] Liao, K. I., \& Yin, M. Ch. (2000). Individual and combined antioxidant effects of seven phenolic agents in human. Journal of Agriculture and Food Chemistry, 48, 2266-2270.

[69] Gurbuz, I. (2003). "Antiulcerogenic activity of some plants used as folk remedy in Tur key," Journal of Ethnopharmacology, vol.88, no.1, pp.93-97, 2003.

[70] Shui, G., \& Peng L. L. (2004). An improved method for the analysis of major antioxidants of Hibiscus esculentus Linn. Journal of Chromatography A, 1048, pp. 17-24.

[71] Atawodi, S. E., Atawodi, J. C., Idakwo, G. A., Pfundstein, B., Haubner, R., Wurtele, G., Spiegelhalder, \& Owen, R. W. (2009). Polyphenol composition and antioxidant potential

[72] Khomsug, P., Thongjaroenbuangam, W., Pakdeenarong, N., Suttajit, M., \& Chantiratikul, P. (2010). Antioxidative Activities and Phenolic Content of Extracts from "Okra" (Abelmoschus esculentus L.) Research Journal of Biological Sciences, 5(4), 310-313.

[73] Adelakun, O. E., Ade-Omowaye, B. I. O., Adeyemi, I. A., \& Van De Venter, M. (2010). Functional properties and mineral contents of a Nigerian "Okra" seed (Abelmoschus esculentus Moench) fl our as influenced by pretreatment. Journal of Food Technology, 8(2), 39-45.

[74] Ansari, N. M., Houlihan, L., Hussain, B., \& Pieroni, A. (2005) Antioxidant activity of five vegetables traditionally consumed by south-Asian migrants in Bradford, Yorkshire, UK. Phytotherapy Research, 19(10), 907-911.

[75] Liao, H, Liu, H., \& Yuan, K. (2012). A new flavonol glycoside from the Abelmoschus esculentus Linn. Pharmagnosy Magazine, 8, 12-5.
[76] Ngoc, T., Ngo, N., Van, T., \& Phung, V. (2008). Hypolipidemic effect of extracts from Abelmoschus esculentus L. (Malvaceae) on Tyloxapol-induced hyperlipidemia in mice. Warasan Phesatchasat, 35, 42-46.

[77] Messing, J., Thöle, C., Niehues, M., Shevtsova, A., Glocker, E., \& Hensel, A. (2014). Antiadhesive properties of Abelmoschus esculentus ("Okra") immature fruit extract against Helicobacter pylori adhesion. PLoS One, 9(1), e84836.

[78] Georgiadisa, N., Ritzoulisa, C., Siouraa, G., Kornezoua, P., Vasiliadoub, C., \& Tsioptsiasa, C. (2011). Contribution of "Okra" extracts to the stability and rheology of oil-in-water emulsions. Food Hydrocolloids, 25(5), 991-999.

[79] Bakre, L. G., \& Jaiyeoba, K. T. (2009). Effects of drying methods on the physicochemical and compressional characteristics of "Okra" powder and the release properties of its metronidazole tablet formulation. Archives of Pharmacal Research, 32 (2), 259-67.

[80] Zaharuddin, N.D., Noordin, M.I, \& Kadivar, Ali. (2014). The Use of Hibiscus esculentus("Okra") Gum in Sustaining the Release of Propranolol Hydrochloride in a Solid Oral Dosage Form. BioMed Research International, Article ID 735891, 8 pages.

[81] Lengsfeld, C., Titgemeyer, F., Faller, G., \& Hensel, A. (2004). Glycosylated compounds from "Okra" inhibit adhesion of Helicobacter pyroli to human gastric mucosa. J Agric Food Chem. 52:1495-503.

[82] Sengkhamparn, N., Verhoef, R., Schols, HA., Sajjaanantakul, T., \& Voragen, AG. (2009). Characterisation of cell wall polysaccharides from "Okra" (Abelmoschus esculentus (L.) Moench) Carbohydr Res. 344:1824-32.

[83] Tomoda, M., Shimizu. N., Gonda, R., Kanari, M., Yamada, H., \& Hikino, H. (1989). Anticomplementary and hypoglycemic activity of "Okra" and hibiscus mucilage. Carbohydr Res. 190:323-8.

[84] Kahlon, TS., Chapman, MH., \& Smith, GE. (2007). In vitro binding of bile acids by "Okra", beets, asparagus, eggplant, turnips, green beans, carrot and cauliflower. Food Chem. 103:676-80.

[85] Sabitha, V., Ramachandran, S., Naveen, K. R., and Panneerselvam, K. (2011). Antidiabetic and antihyperlipidemic potential of Abelmoschus esculentus (L.) Moench. in streptozotocin-induced diabetic rats, J Pharm Bioallied Sci. 3(3): 397-402. 